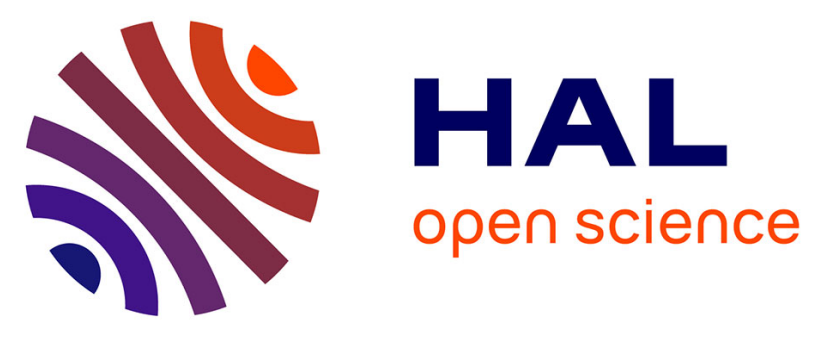

\title{
Lake Ohrid, Albania, provides an exceptional multi-proxy record of environmental changes during the last glacial-interglacial cycle
}

A.-M. Lézine, U. von Grafenstein, N. Andersen, S. Belmecheri, A. Bordon, B. Caron, Jean-Pierre Cazet, Helmut Erlenkeuser, Eric Fouache, C. Grenier, et al.

\section{- To cite this version:}

A.-M. Lézine, U. von Grafenstein, N. Andersen, S. Belmecheri, A. Bordon, et al.. Lake Ohrid, Albania, provides an exceptional multi-proxy record of environmental changes during the last glacialinterglacial cycle. Palaeogeography, Palaeoclimatology, Palaeoecology, 2010, 287 (1-4), pp.116-127. 10.1016/j.palaeo.2010.01.016 . insu-01547092

\section{HAL Id: insu-01547092 \\ https://hal-insu.archives-ouvertes.fr/insu-01547092}

Submitted on 26 Jun 2017

HAL is a multi-disciplinary open access archive for the deposit and dissemination of scientific research documents, whether they are published or not. The documents may come from teaching and research institutions in France or abroad, or from public or private research centers.
L'archive ouverte pluridisciplinaire HAL, est destinée au dépôt et à la diffusion de documents scientifiques de niveau recherche, publiés ou non, émanant des établissements d'enseignement et de recherche français ou étrangers, des laboratoires publics ou privés. 


\title{
Lake Ohrid, Albania, provides an exceptional multi-proxy record of environmental changes during the last glacial-interglacial cycle
}

\author{
A.-M. Lézine ${ }^{\text {a,* }}$, U. von Grafenstein ${ }^{\text {a }}$, N. Andersen ${ }^{\text {b }}$, S. Belmecheri ${ }^{\text {a }}$, A. Bordon ${ }^{\text {a }, ~ B . ~ C a r o n ~}{ }^{\text {c }}$ J.-P. Cazet ${ }^{\text {a }}$, \\ H. Erlenkeuser ${ }^{\text {b }}$, E. Fouache ${ }^{\mathrm{d}}$, C. Grenier ${ }^{\mathrm{a}}$, P. Huntsman-Mapila ${ }^{\mathrm{e}}$, D. Hureau-Mazaudier ${ }^{\mathrm{f}}$, D. Manelli ${ }^{\mathrm{g}}$, \\ A. Mazaud ${ }^{\mathrm{a}}$, C. Robert $^{\mathrm{h}}$, R. Sulpizio ${ }^{\mathrm{i}}$, J.-J. Tiercelin ${ }^{\mathrm{j}}$, G. Zanchetta ${ }^{\mathrm{c}}$, Z. Zeqollari $^{\mathrm{g}}$ \\ a Laboratoire des Sciences du Climat et de l'Environnement, CNRS, CEA, UVSQ-Orme des Merisiers bâtiment 701, 91191 Gif-Sur-Yvette cedex, France \\ ${ }^{\mathrm{b}}$ Leibniz-Laboratory for Radiometric Dating and Stable Isotope Research, 24118 Kiel, Germany \\ c Dipartimento di Scienze della Terra, University of Pisa, via S. Maria 53, 56126, Pisa, Italy \\ d Université de Paris 12, EA 435 Géonat, UMR 8591 CNRS/Paris 1, 61 Avenue du Général de Gaulle 94010 Créteil cedex, France \\ e Harry Oppenheimer Okavango Research Centre, University of Botswana, P/Bag 285, Maun, Botswana \\ ${ }^{\mathrm{f}}$ IUEM, Université de Bretagne occidentale de Brest, Technopôle Brest Iroise, Place Copernic, 29280 Plouzane, France \\ g Geological Survey, Pogradec, Albania \\ h CEREGE, Europôle méditerranéen de l'Arbois, BP 80, 13545 Aix-en-Provence cedex 4, France

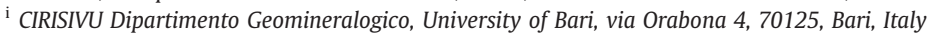 \\ ${ }^{j}$ Géosciences Rennes, Université Rennes 1, bat. 15 - campus de Beaulieu, 263 Avenue du général Leclerc, BP 74205, 35042 Rennes Cedex, France
}

\section{A R T I C L E I N F O}

\section{Article history:}

Received 28 July 2009

Received in revised form 8 January 2010

Accepted 11 January 2010

Available online 15 January 2010

\section{Keywords:}

Ohrid

Albania

Last climatic cycle

Multi-proxy approach

Palaeoenvironments

\begin{abstract}
A B S T R A C T
Multi-proxy analyses on core J02004- 1 recovered from Lake Ohrid $\left(40^{\circ} 55.000 \mathrm{~N}, 20^{\circ} 40.297 \mathrm{E}, 705 \mathrm{~m}\right.$ a.s.l. $)$ provide the first environmental and climate reconstruction in a mountainous area in Southern Europe over the last 140,000 years. The response of both lacustrine and terrestrial environments to climate change has been amplified by the peculiar geomorphological and hydrological setting, with a steep altitudinal gradient in the catchment and a karstic system feeding the lake. The karstic system was active during interglacials, leading to high carbonate production in the lake, and blocked during glacials as a result of extremely cold climate conditions with permafrost in the mountains. At the Riss-Eemian transition (Termination 2) the increase in lacustrine productivity predated forest expansion by about 10,000 years. In contrast, the Late Glacial-Holocene transition (Termination 1) was characterized by the dramatic impact of the Younger Dryas, which initially prevented interglacial carbonate production and delayed its maximum until the midHolocene. In contrast, forest expansion was progressive, starting as early as ca. 38,000 ago. The proximity of high mountains and the probable moderating lake effect on local climate conditions promoted forest expansion, and contributed to make the surroundings of Lake Ohrid favourable to forest refugia during the last glacial, usually steppic, period. Our study of sedimentology, mineralogy, geochemistry, magnetics, palynology and isotopes illustrates the non-linear response of terrestrial and lacustrine ecosystems to similar climate events, and demonstrates the potential of Lake Ohrid as an excellent paleoclimatic archive during the Quaternary.
\end{abstract}

(c) 2010 Elsevier B.V. All rights reserved.

\section{Introduction}

Lake Ohrid, Albania, is an exceptional site for reconstruction of regional climate history over repeated glacial-interglacial fluctuations and its impact on terrestrial and lacustrine ecosystems. Not only the largest southern-European freshwater body $\left(358 \mathrm{~km}^{2}, 289 \mathrm{~m}\right.$ depth), it is likely the oldest in Europe and is renowned for a high level of endemism, with at least 200 lacustrine species described (Stankovic, 1960). The exceptional thickness of sedimentary deposits (Dumurdzanov et al., 2005) makes it

\footnotetext{
* Corresponding author.

E-mail address: anne-marie.lezine@lsce.ipsl.fr (A.-M. Lézine).
}

directly comparable to the Mediterranean lowland site of Tenaghi Philippon in NE Greece which provides a continuous 1.35-million-year pollen record (Tzedakis et al., 2006). Its location at middle altitudes in a rift basin surrounded by high escarpments, within a key area at the confluence of central-European and Mediterranean climatic influences, provides a unique opportunity to study the impact of climate changes on middle- to high-altitude forest ecosystems. Particularly, Lake Ohrid is on exceptional location which allows testing of the "glacial refugia" hypothesis for southern Europe bordering the Mediterranean (e.g., Denèfle et al., 2000; Tzedakis et al., 2002a). Previous studies of the Lake Ohrid sediment record focussed on paleolimnological and sedimentological aspects during a 40,000 years period (Roelofs and Kilham, 1983; Wagner et al., 2008a,b). Here we present for the first time a record of 
environmental and climate change over the last 140,000 years. Attention is paid to selected proxies to discuss the influence of climate change on the karstic system and lake hydrology, as well as on regional vegetation response to glacial-interglacial variations.

\section{Modern setting}

Lake Ohrid lies in a strongly asymmetric, $\mathrm{N}-\mathrm{S}$ oriented half-graben at the Macedonia-Albania border. It is bounded by faults running $\mathrm{N}$ to NNE which affect, to the north and east, carbonate rocks of Triassic and Jurassic age, and ophiolitic rocks of Jurassic age to the south-west (Fig. 1).
The southern end of the basin connects with a small graben filled by Pliocene continental mudstones and sandstones, overlain by fluviolacustrine sediments of Holocene age (Nicot and Chardon, 1983). The basin is filled by several hundred meters of sediments deposited since around $8.5 \mathrm{Ma}$ (Dumurdzanov et al., 2005). The modern lake is holomictic. Today roughly half of its water is derived from a number of springs located in the SE part of the lake, draining a karstic system which, in turn, is fed by water from nearby Lake Prespa and infiltration of rainwater ( $700 \mathrm{~mm} / \mathrm{yr}$ on average) in the Galicica mountain range. The remaining water comes from rivers (e.g., the Sateska River to the north) and direct precipitation. A single outlet (the Black Drin River) to the

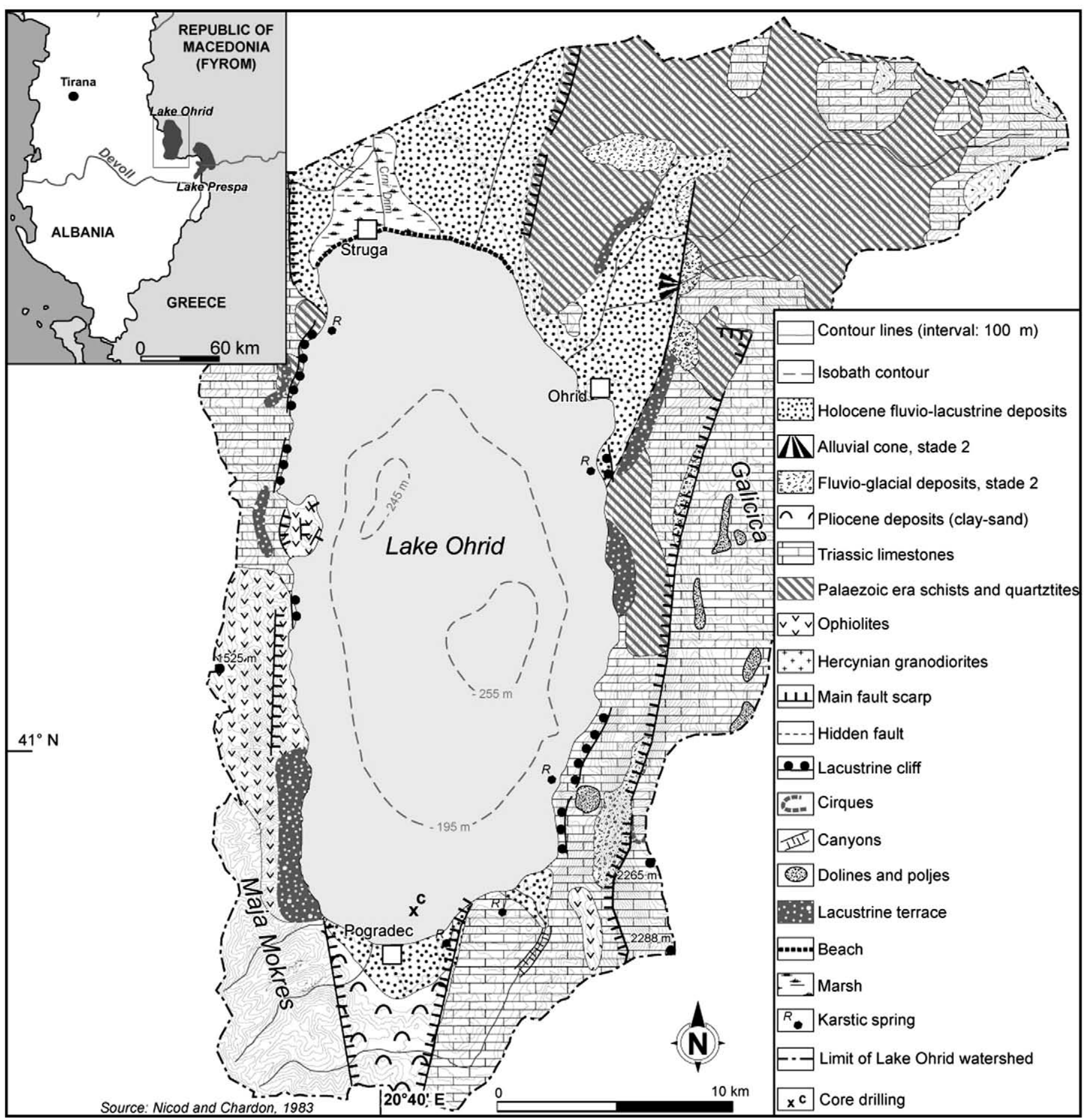

Fig. 1. Geological/geomorphological map of the Lake Ohrid basin, southern Balkan, showing the location of the core site. 
north and significant evaporation (estimated at $1145 \mathrm{~mm} / \mathrm{yr}$ ) complete the water budget (Matzinger et al., 2006). The small size of the Lake Ohrid drainage basin $\left(2600 \mathrm{~km}^{2}\right)$ and its large volume $\left(55.4 \mathrm{~km}^{3}\right)$ lead to a water residence time of about 70 yrs (Matzinger et al., 2006). The catchment area covers a large altitudinal range, from $700 \mathrm{~m}$ to more than $2200 \mathrm{~m}$. The mean annual temperature is $11.5^{\circ} \mathrm{C}$, with winter temperatures varying from $-2.3{ }^{\circ} \mathrm{C}$ to $6.6^{\circ} \mathrm{C}$ and summer temperatures from $10.5^{\circ} \mathrm{C}$ to $22.3^{\circ} \mathrm{C}$. Precipitation is principally during winter and spring. As a result of the high topography, the vegetation is distributed in altitudinal belts with mixed deciduous forests including Carpinus orientalis, Quercus trojana, Q. frainetto, Q. cerris at lake level, followed by Fagus moesiaca, Abies alba, A. borisii-regis at the upper limit of the forest, and a sub-alpine grassland with Juniperus excelsa above $1800 \mathrm{~m}$ in the Mali i Thate mountains to the south-east.

\section{Materials and methods}

\subsection{Core J02004-1}

Core J02004-1 consists of two series of core sections (each up to $3 \mathrm{~m}$ long) recovered ca. $5 \mathrm{~m}$ apart from a single site in the southwestern part of the lake $\left(40^{\circ} 55.000 \mathrm{~N}, 20^{\circ} 40.297 \mathrm{E}, 705 \mathrm{~m}\right.$ a.s.l.). The uppermost ca. $10 \mathrm{~m}$ of sediment were recovered in consecutive $3-\mathrm{m}$ long sections using a hammer-driven Niederreiter piston corer of $63 \mathrm{~mm}$ diameter. To obtain a continuous sedimentary record four sections were recovered from the first hole (JO2004-1), and three sections with a planned depth offset of $1.5 \mathrm{~m}$ from the second hole (JO2004-1a). The overlapping sections were visually cross-correlated using marker layers clearly identified in both sequences, and the resulting composite profile was checked for consistency using the magnetic susceptibility record. The depth information used in the paper refers to a composite linear master depth scale (MCD). In addition to the core sediments, 15 samples taken from a variety of rocks and sediments outcropping in the catchment basin of Lake Ohrid have been studied for mineralogical investigations of the bulk and clay fractions and geochemical analyses.

\subsection{Magnetic susceptibility}

Core sections were sub-sampled with U-channels at the core repository of the Laboratoire des Sciences du Climat et de l'Environnement (LSCE) at Gif-sur-Yvette (France). The volume low-field susceptibility $(\kappa)$ was measured at a high resolution. $\kappa$ is determined by the amount of ferro/ferri magnetic grains, but mineralogical changes and grain size variations may also influence the susceptibility signal. Paramagnetic material (clay) and diamagnetism also contribute to $\kappa$ when the magnetic grain content is low. Measurements of the low field bulk susceptibility $(\kappa)$ were performed using a small diameter Bartington sensor loop mounted in line with a track system designed for u-channel.

\subsection{Sedimentology, mineralogy and sediment geochemistry}

Sediment facies were visually described on bulk samples. In addition, one hundred and ninety samples were analysed for bulk and clay mineral investigations. Each sample was divided into two sub-samples: one sub-sample was crushed in a grinder and pressed into a holder for bulk mineral analyses. The other sub-sample was washed on a $63 \mu \mathrm{m}$ mesh sieve. The $<63 \mu \mathrm{m}$ fraction was decalcified using a solution of $10 \% \mathrm{HCl}$, rinsed with de-ionized water, and deflocculated through repeated centrifugation. The clay fraction $(<2 \mu \mathrm{m})$ was decanted and deposited onto a glass slide. X-ray diffraction (XRD) analyses were conducted on natural clay slides after ethylene-glycol solvation and heating at $490{ }^{\circ} \mathrm{C}$ for $2 \mathrm{~h}$. Determination of percent bulk and clay minerals was based on the respective XRD peak areas, using MacDiff version 3 software (Petschick, 1998); the relative error is $\sim 5 \%$.
Samples subjected to bulk geochemical analyses were processed at UMR 6538 "Domaines Océaniques”, IUEM-UBO, Brest, France. Major elements were measured by ICP-AES with an ISA Jobin-Yvon JY 70 Plus apparatus. Calibrations were checked using the GIT-IWG (Groupe International de Travail-International Working Group) BE-N, WS-E, PM-S, AC-E and the CCRMP (Canadian Certified Reference Materials Project) LKSD-1 international standards. Trace element and rare earth element (REE) measurements were conducted by ICP-MS using a Finnigan Element 2 ICP-MS. Results obtained for the CCRMP (Canadian Certified Reference Materials Project) LKSD-1 were reproducible with precisions for trace elements $<5 \%$, except for $\mathrm{Zr}$ and Hf which were not used to characterize the samples.

\subsection{Dating procedures}

\subsubsection{Radiocarbon measurements}

Seven AMS radiocarbon measurements were performed on terrestrial organic matter and charcoal remains. The ${ }^{14} \mathrm{C}$ activity was determined by UMS-ARTEMIS (Pelletron 3MV) AMS Facilities. Raw ${ }^{14} \mathrm{C}$ dates were converted to calibrated ages using CALIB 5 (Stuiver et al., 2005) except for the oldest radiocarbon age, for which polynomial equations (Bard, 1998) have been used.

\subsubsection{Tephrochronology}

For tephrochronology, the core was continuously screened at $1-\mathrm{cm}$ intervals for volcanic particles (glass shards, magmatic crystals, volcanic lithics). The sediment was washed and sieved at $125 \mu \mathrm{m}$ and $40 \mu \mathrm{m}$ using distilled water. The sediment fraction less than $40 \mu \mathrm{m}$ was collected using a paper filter and progressively dried through a water pump. The sediment fraction 40-125 $\mu \mathrm{m}$ was carefully inspected under stereo microscope. Chemical analyses on glass shards from tephra were performed at the Dipartimento di Scienze della Terra (University of Pisa), using an EDAX-DX micro-analyser (EDS analyses) mounted on a Philips SEM 515 (operating conditions: $20 \mathrm{kV}$ acceleration voltage, $100 \mathrm{~s}$ live time counting, $10^{-9} \mathrm{~A}$ beam current, ZAF correction). Instrument calibration and performance are described in Marianelli and Sbrana (1998). The major-element chemistry of crystal-free glass shards were used to classify the individual tephra layers and correlate them to different archives. SEM back-scattering images were used to describe the texture of the ground mass and to select micro-crystals for micro-analyses.

\subsection{Pollen analysis}

One hundred and fifty five samples were taken at 1 to $15-\mathrm{cm}$ intervals for pollen analyses. Samples were processed using the standard HF method (Faegri and Iversen, 1989) and sieved on a 5- $\mu \mathrm{m}$ mesh. Addition of a known amount of exotic makers (Lycopodium) allowed calculation of pollen concentrations (grains per $\mathrm{cm}^{3}$ of dry sediment) and influx values (grains per $\mathrm{cm}^{2}$ per year). In total 110 different pollen types were identified for a mean pollen sum of 450 grains per sample (maximum count $=1480$ grains). Pollen data are expressed as percentages calculated against a sum of all the determined pollen types except aquatics, spores (bryophytes and ferns) and damaged grains. Pollen grains were determined using regional pollen atlases from Europe and the Mediterranean (Reille, 1992; Chester and Raine, 2001).

\subsection{Ostracod isotope studies}

Ostracod shells were extracted from $1-\mathrm{cm}$ sediment slices taken at $5-\mathrm{cm}$ intervals throughout the core, with the exception of a few continuously sampled sections at major lithostratigraphic transitions (Belmecheri et al, 2009). For sample preparation, the sediment was disaggregated with $\mathrm{H}_{2} \mathrm{O}_{2}$ and gently wet-sieved. The $>125 \mu \mathrm{m}$ fraction was washed with ethanol and dried at room temperature. Ostracod shells were extracted and cleaned. Ostracod species identification 
follows Klie (1939a,b; 1942) and Mikulić (1961). The stable-isotope composition of the shells was analyzed at the Leibniz Laboratory in Kiel using a Finnigan MAT 251 mass spectrometer equipped with an automatic carbo-Kiel $\mathrm{CO}_{2}$ preparation device. Isotope ratios are given relative to the PDB standard in the usual notation with a total accuracy on the order of $0.05 \%$ and $0.08 \%$ for $\delta^{13} \mathrm{C}$ and $\delta^{18} \mathrm{O}$, respectively.

\section{Data (Fig. 2)}

\subsection{The sedimentary record}

\subsubsection{The present-day catchment basin of Lake Ohrid}

Mineralogical investigations of the bulk and clay fractions have been conducted on a variety of rocks and sediments outcropping in the catchment basin of Lake Ohrid (Table 1). Lizardite and clinochlore are the main constituents of the ophiolites, which weather primarily into smectite. The bulk composition of molasse deposits, Neogene and Quaternary sediments are largely dominated by quartz, associated with feldspars, clay minerals and, locally, a proportion of ophiolite minerals (lizardite and clinochlore). Clay minerals include irregular mixed-layers of illite-smectite and chlorite-smectite types, illite, smectite and kaolinite. However, the relative proportions of the minerals vary strongly according to the nature of the substrates in the different parts of the drainage basin. In addition, irregular mixedlayered clays of illite-smectite type contain a high proportion of illite layers and probably reflect subsequent weathering of illite in the porous terrigenous sediments. The carbonates that outcrop in the drainage basin consist of calcite but do not contain other types of minerals and are not weathered into clay minerals. It is remarkable that calcite is absent or occurs in very minor abundances of less than $5 \%$ in molasse deposits and other terrigenous sediments of Pliocene and Quaternary age (Fig. 2).

Geochemically, the ophiolitic formations are dominated by $\mathrm{SiO}_{2}$ and $\mathrm{MgO}$, with minor amounts of $\mathrm{Fe}_{2} \mathrm{O}_{3}, \mathrm{CaO}$ and $\mathrm{Al}_{2} \mathrm{O}_{3}$. The TriassicJurassic carbonates are purely formed by $\mathrm{Mg}$-calcite (56 wt.\% $\mathrm{CaO}$ and $0,45 \mathrm{wt} . \% \mathrm{Mg}$ ), and the continental mudstones and sandstones of Pliocene age at the southern end of the Ohrid basin are characterized by $\mathrm{Al}_{2} \mathrm{O}_{3}$ and $\mathrm{CaO}$, with minor quantities of $\mathrm{Fe}_{2} \mathrm{O}_{3}$ and $\mathrm{K}_{2} \mathrm{O}$.

\subsubsection{Core J02004-1}

The sediment series generally includes calcareous and siliciclastic elements. Calcareous elements occur principally in the form of clay-sized to sand-sized aggregates and biogenic remains (ostracods), which are especially abundant from the top of the core to $75 \mathrm{~cm}$ (calcareous clay and sand to calcareous mud) and from 470 to $924 \mathrm{~cm}$ (calcareous clay to sandy calcareous mud). Siliciclastic elements are especially abundant from 75 to $470 \mathrm{~cm}$ (clay, silty clay and sand) and from $924 \mathrm{~cm}$ to the bottom of the core (silty clay). Sandy intervals at $188 \mathrm{~cm}$ and $240-246 \mathrm{~cm}$ are conspicuous tephra layers. The sediment color ranges from beige to grey, the darkest colors being associated with occurrences of organic remains, principally plant debris.

Mineralogical assemblages of the core's bulk sediment are dominated by quartz and calcite. Quartz is associated with smaller proportions of feldspars and clay minerals. Similar, quartz dominated

Table 1

Mineralogical and geochemical composition of the main geological outcrops in the Ohrid-Maliq basin.

\begin{tabular}{|c|c|c|c|c|c|c|c|c|}
\hline Nature of substrate & Clay minerals (\%) & Quartz (\%) & Feldspars (\%) & Pyroxenes (\%) & Ophiolite minerals (\%) & Calcite (\%) & Dolomite (\%) & Gypsum (\%) \\
\hline Pliocene fluviatile deposits & 10 & 77 & 12 & 1 & 0 & 0 & 0 & 0 \\
\hline Triassic limestones & 0 & 0 & 0 & 0 & 0 & 100 & 0 & 0 \\
\hline Molasse & 25 & 52 & 19 & 0 & 2 & 0 & 0 & 2 \\
\hline Ophiolite (weathered) & 2 & 0 & 8 & 0 & 67 & 2 & 21 & 0 \\
\hline Middle Miocene claystones and limestones & 20 & 44 & 8 & 0 & 0 & 24 & 0 & 4 \\
\hline Pliocene claystones and sandstones & 18 & 54 & 16 & 0 & 8 & 4 & 0 & 0 \\
\hline Ophiolite & 0 & 0 & 0 & 1 & 99 & 0 & 0 & 0 \\
\hline Triassic limestones & 1 & 0 & 0 & 0 & 0 & 99 & 0 & 0 \\
\hline Late Cretaceous limestones & 2 & 1 & 0 & 0 & 0 & 97 & 0 & 0 \\
\hline ophiolite & 2 & 0 & 0 & 1 & 95 & 0 & 2 & 0 \\
\hline Lower Miocene claystones and limestones & 22 & 38 & 10 & 0 & 0 & 15 & 15 & 0 \\
\hline Ophiolite & 0 & 0 & 0 & 0 & 100 & 0 & 0 & 0 \\
\hline Nature of substrate & Lizardite (\%) & Chlo & rite (\%) & Illite (\%) & Mixed-layered clays (\%) & Smec & tite (\%) & Kaolinite (\%) \\
\hline Pliocene fluviatile deposits & 0 & 0 & & 17 & 65 & 4 & & 14 \\
\hline Molasse & 0 & 0 & & 7 & 73 & 0 & & 20 \\
\hline Ophiolite (weathered) & 81 & 0 & & 0 & 0 & 19 & & 0 \\
\hline Middle Miocene claystones and limestones & 0 & 11 & & 25 & 64 & 0 & & 0 \\
\hline Pliocene claystones and sandstones & 0 & 0 & & 17 & 0 & 40 & & 43 \\
\hline Late Cretaceous limestones & 0 & 0 & & 51 & 19 & 0 & & 10 \\
\hline Ophiolite & 97 & 0 & & 0 & 0 & 3 & & 0 \\
\hline Lower Miocene claystones and limestones & 0 & 19 & & 34 & 47 & 0 & & 0 \\
\hline Middle Miocene claystones and limestones & 5 & 0 & & 11 & 84 & 0 & & 0 \\
\hline Nature of substrate & $\mathrm{SiO}_{2}$ & $\mathrm{Al}_{2} \mathrm{O}$ & & $\mathrm{Fe}_{2} \mathrm{O}_{3}$ & $\mathrm{MgO}$ & $\mathrm{CaO}$ & & $\mathrm{K}_{2} \mathrm{O}$ \\
\hline Pliocene fluviatile deposits & 60.6 & 14.8 & & 8.12 & 1.38 & 0.77 & & 2.08 \\
\hline Triassic limestones & 0.75 & 0.1 & & 0.07 & 0.54 & 58.25 & & 0.03 \\
\hline Molasse & 65.8 & 13.1 & & 5.26 & 1.16 & 0.42 & & 1.71 \\
\hline Ophiolite (weathered) & 41.5 & 0.5 & & 8.3 & 35.5 & 0.75 & & 0.01 \\
\hline Middle Miocene claystones and limestones & 47.8 & 9.7 & & 4.57 & 3.17 & 14.1 & & 1.97 \\
\hline Pliocene claystones and sandstones & 67.2 & 11.2 & & 4.78 & 1.03 & 4.88 & & 2.00 \\
\hline Ophiolite & 38.7 & 0.1 & & 7.4 & 37.6 & 0.20 & & 0.01 \\
\hline Triassic limestones & 0.3 & 0.0 & & 0.04 & 0.45 & 56.00 & & 0.03 \\
\hline Late Cretaceous limestones & 1.15 & 0.2 & & 0.16 & 0.59 & 56.00 & & 0.09 \\
\hline Ophiolite & 38.65 & 0.4 & & 8.2 & 36.4 & 0.16 & & 0.00 \\
\hline Lower Miocene claystones and limestones & 44.5 & 11.9 & & 6.25 & 5.72 & 10.50 & & 2.18 \\
\hline Ophiolite & 39 & 0.2 & & 7.7 & 36.8 & 0.15 & & 0.01 \\
\hline Middle Miocene claystones and limestones & 1.35 & 0.2 & & 0.16 & 3.84 & 55.00 & & 0.07 \\
\hline
\end{tabular}




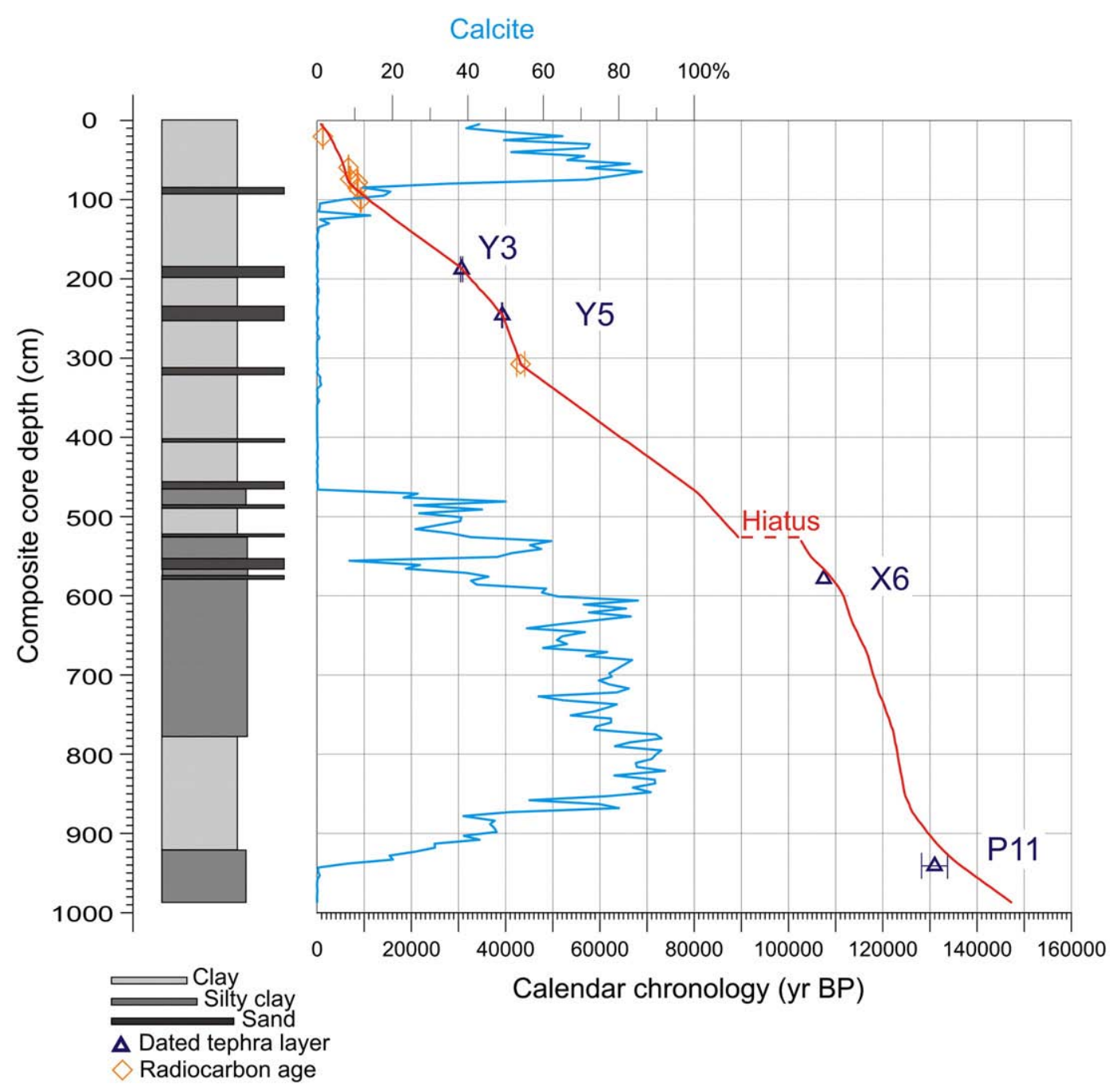

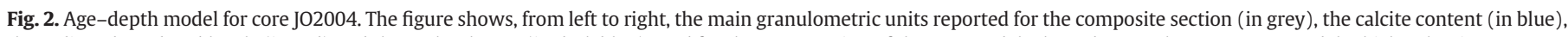

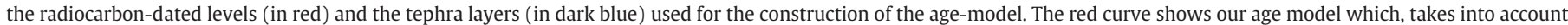
the gap in the sedimentary record corresponding to a large part of the St Germain I pollen zone (see Belmecheri et al., 2009 for details).

mineralogical assemblages are also found in alluvial deposits and other Neogene and Quaternary sediments of the region. Mineral particles are typically terrigenous and originate from erosion from the adjacent drainage basin by running waters. However, feldspars significantly increase at several intervals, where they may result from in-situ alteration of tephra layers. Other terrigenous elements include pyroxenes and ophiolite minerals (principally lizardite and clinochlore), derived from ophiolitic formations which largely outcrop in the drainage basin. When present, calcite may represent up to $90 \%$ of the bulk sediment. Calcite occurs as biogenic elements (ostracods principally) or silt-sized to clay-sized aggregates.

Clay mineral assemblages are dominated by illite, which occurs in significant amounts in alluvial deposits and other terrigenous sediments of the drainage basin. In both cases, illite is associated to variable percentages of chlorite, kaolinite, and random mixed-layered clays. The association of minerals derived from poorly weathered substrates (illite, chlorite, random mixed-layered clays) and from areas of intense chemical weathering (kaolinite) probably results from intense erosion of soils and substrates in adjacent mountain areas by run-off. It is noteworthy that maximum abundances of illite and associated minerals coincide with occurrences of calcite. Maximum abundances in illite and chlorite alternate with intervals of abundant smectite. In the modern world, abundant smectite is often found in warm areas of seasonal precipitation (Chamley, 1989; Weaver, 1989). Its formation is strongly enhanced on mafic substrates, and small proportions of the mineral have even been described in the weathering profiles of basaltic substrates of cold areas, for example in modern West Antarctica (Campbell and Claridge, 1998). Ophiolite outcrops of the drainage basin of Lake Ohrid have shown to weather into smectite. Maximum abundances of smectite coincide with maximum contents of clay minerals and quartz in the bulk sediment, indicating significant development of weathering and erosion in the catchment.

\subsection{Datations}

\subsubsection{Radiocarbon measurements}

Radiocarbon measurements (Table 2) from the uppermost part of the core are in chronological order from $8275 \pm 40(100,5 \mathrm{~cm})$ to $1285 \pm 30{ }^{14} \mathrm{Cyr}$ BP $(20.5 \mathrm{~cm})$. However, it was impossible to obtain sufficient organic matter for reliable dating below $100,5 \mathrm{~cm}$. The age of $39,100 \pm 1200{ }^{14} \mathrm{C}$ yr BP $(307,6 \mathrm{~cm})$ is therefore only indicative.

\subsubsection{Tephra}

Volcanic material was recognised at $188,240-246,575-576 \mathrm{~cm}$ and 939-941 cm (Table 3). Two of these tephra layers (at $188 \mathrm{~cm}$ and 
Table 2

Radiocarbon measurements

\begin{tabular}{|c|c|c|c|c|c|c|c|}
\hline Laboratory number (Artemis-Saclay) & Sample & Mean composite depth $(\mathrm{cm})$ & ${ }^{14} \mathrm{C}$ age & & Error & Calendar ages BP (one sigma) & Material \\
\hline SacA 8010 & JO2004-1A020 & 20.5 & 1285 & \pm & 30 & $1181-1274$ & Terrestrial plant remains \\
\hline SacA 8011 & J02004-1A059 & 59.5 & 5840 & \pm & 35 & $6572-6726$ & Terrestrial plant remains \\
\hline 002653 & J02004-1A074 & 74 & 6130 & \pm & 80 & $6937-7158$ & Terrestrial plant remains \\
\hline 002654 & JO2004-1A078 & 78.5 & 7800 & \pm & 80 & $8451-8693$ & Terrestrial plant remains \\
\hline SacA 8012 & JO2004-1A085 & 85.5 & 7850 & \pm & 40 & $8585-8700$ & Terrestrial plant remains \\
\hline SacA 8013 & JO2004-1A100 & 100.5 & 8275 & \pm & 40 & $9141-9400$ & Terrestrial plant remains \\
\hline 002655 & JO2004-1B113 & 307.6 & 39,100 & \pm & 1200 & 42,000 & Terrestrial plant remains \\
\hline
\end{tabular}

$240-246 \mathrm{~cm}$ ) were visible as discrete sandy-silty layers, whereas the other two are crypto-tephra $(575-576 \mathrm{~cm}$ and $939-941 \mathrm{~cm})$ mixed with lake and clastic sediments. A detailed description of the tephra layers of the studied core sequence and in-depth discussion of their correlation and origin can be found in Caron et al. (submitted for publication). The chemical composition of glass shards and micropumice fragments permitted the correlation of Lake Ohrid samples to other tephra layers already recognised in the Mediterranean basin: the tephra layer at $188 \mathrm{~cm}$ has been correlated with the Y3 tephra layer dated at 30,670 $\pm 230 \mathrm{yr}$ BP (Keller et al., 1978; Zanchetta et al., 2008). The base of the tephra at $240-246 \mathrm{~cm}$ has been correlated with the Y5/ Campanian Ignimbrite tephra layer, widely recognised in the centraleastern Mediterranean and Eastern Europe mainland (Keller et al., 1978; Pyle et al., 2006; Giaccio et al., 2008; Aksu et al., 2008; Calanchi and Dinelli, 2008) and dated to 39,280 $\pm 110 \mathrm{yr}$ BP (De Vivo et al., 2001). The crypto-tephra material at $575-576 \mathrm{~cm}$ depth is correlated with the X6 tephra layer (Keller et al., 1978) on the basis of the good compositional match with analyses from Lago Grande di Monticchio (Wulf et al., 2006) and the C-31 marine tephra layer (Brauer et al., 2007; Paterne et al. 2008) (Fig. 3). The ${ }^{40} \mathrm{Ar} /{ }^{39} \mathrm{Ar}$ age of $107,000 \pm 2000 \mathrm{yr}$ BP for the $\mathrm{X}-6$ tephra (Keller et al., 1978) is in good agreement with the suggested age of $108,430 \mathrm{yr}$ BP obtained from the varve-supported Monticchio chronology and with the suggested age of C-31 tephra layer at $107,000 \mathrm{yr}$ BP (Paterne et al., 2008). The volcanic fragments of the crypto-tephra at $939-941 \mathrm{~cm}$ depth are a Pantellerite (Civetta et al., 1984, 1988). In marine cores from the Mediterranean (Paterne et al., 2008), two tephra layers match the lithology and composition of this tephra layer, namely P11 (131,000 yr BP) and P12 (164,000 yr BP). Both tephra layers originate from Pantelleria Island, and correspond to the Ignimbrite P (dated at $133,100 \pm 3300 \mathrm{yr} \mathrm{BP}$ ) and to the Welded Tuff S (dated at ca. 163,000 yr BP), respectively (Mahood and Hildreth, 1986). Stratigraphic considerations support correlation of the $943-941 \mathrm{~cm}$ Ohrid tephra with the P11 marine tephra layer, and thus with Ignimbrite

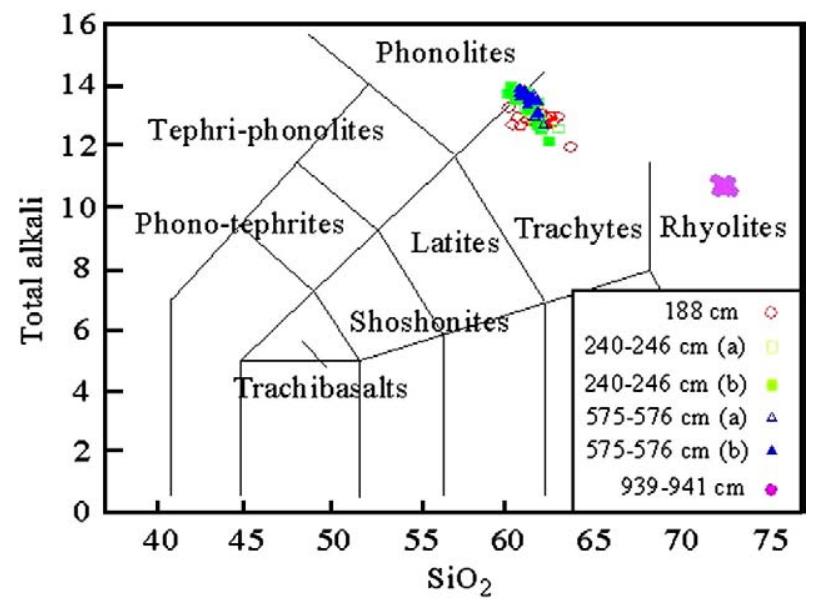

Fig. 3. Total alkali vs. silica diagram of glass composition of the recognised tephra layers (a) and (b) indicate two different compositional groups within the same tephra layer.
P deposits on Pantelleria. The tephra at $943-941 \mathrm{~cm}$ is located within the rising calcite content and increasing arboreal pollen values which unequivocally indicate that this tephra was deposited close to the inception of the Last Interglacial. Although the onset of the Last Interglacial may have been recorded at different times in different archives (e.g., Sánchez Goñi et al., 2005), a putative age of 164,000 yr BP (which correspond to P12 tephra layer) is several ten of thousands of years too old for the inception of the Last Interglacial around the Mediterranean (e.g. Sánchez Goñi et al., 1999, 2005).

\subsection{Pollen}

The Ohrid pollen record shows the classical opposition between Arboreal Pollen (AP) and Non Arboreal Pollen (NAP) percentages throughout the last climatic cycle (Bordon, 2009). AP pollen dominate with percentages higher than $80 \%$ between 879 and $597 \mathrm{~cm}, 566$ and $537 \mathrm{~cm}$, at $477 \mathrm{~cm}$, and then from $100.5 \mathrm{~cm}$ to the top of the sequence. A minor peak of $77 \%$ is recorded between 335 and $280 \mathrm{~cm}$. Trees and shrubs are mainly Pinus (maximum =73\%), Abies (54\%), Quercus robur (36\%), Carpinus (14\%), Juniperus (13\%), Quercus ilex (12\%), Hippophae rhamnoides (8.6\%), Tilia (7.7\%), Fagus (7\%), Betula (4.6\%), Olea (3\%) and Corylus $(1.7 \%)$ recording distinct influences from Mediterranean and temperate middle- and high-elevation forests. Three pollen types of steppic origin dominate the herbaceous plant communities (Artemisia, Poaceae and Chenopodiaceae) with maximum percentages of $46 \%$ $(228 \mathrm{~cm}), 30 \%(213 \mathrm{~cm})$ and 15\% (516.9 cm), respectively.

In detail, changes in forest vegetation record the spread of Pinus and Quercus robur, associated, to a lesser extent, with Quercus ilex and Tilia during the first phase of forest expansion $(878.9-791 \mathrm{~cm})$. These taxa strongly decline (Pinus, Q. robur, Q. ilex) or disappear (Tilia) to the benefit of Abies which massively expands (791-596.9 cm), in association with Carpinus (peak reached at $737.9 \mathrm{~cm}$ ) then with Picea (peak reached at $666.9 \mathrm{~cm}$ ). Abies and Pinus strongly increase during the following forest phases at levels centred at $556.9 \mathrm{~cm}$ and $476.9 \mathrm{~cm}$, then between 125.5 and $50.5 \mathrm{~cm}$ in association with $Q$. robur. The forest phase recorded between 329.6 and $279.6 \mathrm{~cm}$ displays a slightly different pattern with Pinus dominating the pollen assemblage and Q. robur, Picea and Abies reaching $10 \%$ or less, only.

\subsection{Ostracods}

The lowermost part of the core, from the base to $940 \mathrm{~cm}$, is devoid of ostracod valves. At $940 \mathrm{~cm}$ the ostracod valves appear and reach a maximum of high species diversity at $880 \mathrm{~cm}$. Ostracod valves are well preserved and taxonomically diversified during the hole the interval from $940 \mathrm{~cm}$ to $470 \mathrm{~cm}$. No ostracod valves are found during the following interval from $470 \mathrm{~cm}$ to $120 \mathrm{~cm}$, apart from some broken valves found in a short 10-cm-thick interval between $320 \mathrm{~cm}$ and $340 \mathrm{~cm}$. At $120 \mathrm{~cm}$, we record the re-occurrence of the ostracod valves which are present until the top of the core.

The mean candonid species $\delta^{13} \mathrm{C}$ record starts with values around $0.5 \%$ at $940 \mathrm{~cm}$ followed by an increasing trend which continues until $890 \mathrm{~cm}$ reaching a maximum of $2 \%$. After $890 \mathrm{~cm}, \delta^{13} \mathrm{C}$ decreases rapidly to $-0.5 \%$ and drop to a minimum of $-2 \%$ around $780 \mathrm{~cm}$ The 
period between $750 \mathrm{~cm}$ and $550 \mathrm{~cm}$ is marked by two consecutive positive excursions, with a first maximum of $2 \%$ at $570 \mathrm{~cm}$ and a second maximum of $0.5 \%$ at $550.5 \mathrm{~cm}$. The period after the hiatus is marked by a single positive excursion starting with $-1 \%$ at $530 \mathrm{~cm}$, increasing to $1.2 \%$ o between $520 \mathrm{~cm}$ and $490 \mathrm{~cm}$ to end with $-1 \%$ just after $480 \mathrm{~cm}$.

The candonid valve fragments found in the short 10-cm interval at $340 \mathrm{~cm}$ show high $\delta^{13} \mathrm{C}$ values around $1 \%$ close to the values before $890 \mathrm{~cm}$ and the positive excursion around $750 \mathrm{~cm}$ and $550.5 \mathrm{~cm}$.

In the upper most part of the record, $\delta^{13} \mathrm{C}$ values of the candonid valves start with moderately low values between $0 \%$ and $-1 \%$ at $110 \mathrm{~cm}$. However, during this period ostracod mean $\delta^{13} \mathrm{C}$ values scatter around $-0.5 \%$, interrupted by a very short excursion to very low $\delta{ }^{13} \mathrm{C}$ values below $-3 \%$ around $70 \mathrm{~cm}$.

\section{Environmental reconstruction}

\subsection{A sedimentological record controlled by a karstic system}

The most striking characteristic of the Lake Ohrid sediment sequence is the strong variation in calcite, which dominates from 870 to $590 \mathrm{~cm}$ and from 80 to $0 \mathrm{~cm}$, and is absent from other intervals (Fig. 2). When present, calcite may represent up to $90 \%$ of the bulk sediment. Besides biogenic remains such as ostracod shells (not exceeding more than $0.1 \%$ of the sample mass), calcite principally occurs as angular to sub-angular, generally silt-sized particles. Calcite is either absent, or only occurs as trace amounts of less than $5 \%$, in alluvial and molasse sediments that outcrop in the adjacent drainage basin. In addition, sandy intervals of the core which may indicate some degree of reworking from shallower, nearshore areas of the lake which are closer to limestone outcrops, generally contain smaller proportions of calcite than adjacent silt and clay sediments. Therefore, we consider the contribution of terrigenous calcite as limited. Calcite aggregates of similar morphology have been described in modern low salinity to fresh water environments of temperate and tropical latitudes (Stabel, 1986; Talbot and Allen, 1996) saturated in $\mathrm{CO}_{3}^{2-}$ (Eugster and Kelts, 1983) where they are considered of authigenic origin. Similar calcite aggregates also characterize Holocene paleolake deposits of Yemen where matching carbon isotope distribution in bivalve shells and bulk sediment suggest coeval, in-situ formation of biogenic and abiotic calcite (Lézine et al., 1998). Based on identical mineralogy, morphology, and occurrence of the latter calcite aggregates, we consider calcite particles in Lake Ohrid sediments to be of predominantly authigenic origin. Limestone outcrops in the drainage basin of Lake Ohrid are probably dissolved by rain water and soil acids. Calcium and carbonate ions are transported to the lake by run-off and via the karst aquifer. There, carbonate/bicarbonate reactions and photosynthesis progressively decrease the availability of free hydrogen ions and raise the $\mathrm{pH}$. Dissolved carbonate and calcium ions are used by aquatic biota (ostracods, molluscs) to build their mineral parts, or precipitate directly in the epilimnin when at high concentrations, for example during spring and summer algae blooms. At long time scales, calcite formation may either occur during intervals of high precipitation when transport of dissolved calcium and carbonate ions to the lake increase; high evaporation, which increases their concentration in the water; and/or elevated temperature, which lowers the saturation threshold for calcite. These conditions most likely occur during interglacials. Conversely, calcite deposition is hampered under dry/cold climatic conditions due to decreased influence of running waters and the cessation of the karstic flow. In addition, cold conditions increase the capacity of lake waters to absorb carbon dioxide and reduce photosynthesis. This in turn fosters the concentration of hydrogen ions and decreases the $\mathrm{pH}$ of the lake waters. Such conditions likely correspond to glacial intervals.

In the absence of dilution by calcite particles, siliciclastics dominate during cold/dry intervals. Siliciclastic assemblages are diversified. They include typically terrigenous elements such as quartz, feldspars, clay minerals (mainly illite, associated with variable percentages of chlorite, kaolinite, random mixed-layered clays and smectite), pyroxenes, and ophiolite minerals (lizardite and clinochlore). Lacustrine siliciclastic assemblages are very similar in composition to those found in molasse and alluvial deposits, suggesting that they are derived from the erosion of the catchment basin by running waters. The presence of clay minerals of diverse origins indicates concomitant erosion of soils, sediments, and substrates. It is remarkable that maximum abundances in illite and chlorite coincide with intervals of highest calcite contents, indicating that strong precipitation also favoured an intense erosion of poorly weathered substrates in the drainage basin of the lake. Intervals of increased smectite contents (which coincide with low calcite and high quartz contents) suggest that dry/cold climatic conditions nevertheless allowed some degree of chemical weathering of the ophiolitic substrates. Such a transient interval of chemical weathering with smectite formation and erosion, is recognized around $490-530 \mathrm{~cm}$. However, climate improvement (in terms of precipitation and/or temperature) was insufficient during this interval to allow an extensive precipitation of authigenic calcite in the lake.

\subsection{A complex chronological framework}

The age model (see discussion in Belmecheri et al., 2009) (Fig. 4) shows that the Ohrid sequence extends back to about $140,000 \mathrm{yr}$ BP. It fits remarkably well with the orbitally-tuned environmental history of southern Europe (Tzedakis, 2005; Sirocko et al., 2007; Sánchez Goñi, 2007) (Fig. 5) from terrestrial pollen records in Greece (e.g., Tenaghi Philippon) and marine isotope records along the southern European margin (e.g., ODP 980). It also fits with the chronology of pollen events at Monticchio in Italy (Brauer et al., 2007) (Fig. 6). According to this, the Eemian interglacial started at $127,000 \mathrm{yr}$ BP and lasted roughly $17,000 \mathrm{yr}$ which corroborates earlier estimations in southern Europe (Tzedakis et al. 2002b; Brauer et al., 2007; Brewer et al., 2008).

A major hiatus of roughly 12,000 years corresponds to a large part of the St. Germain I period. The stratigraphical and chronological position of this hiatus is confirmed by the absence in our record of tephra layer X5, dated at 105,000 $\pm 2000 \mathrm{yr}$ BP (Keller et al., 1978; Kraml, 1997; Wulf et al., 2006; Di Vito et al., 2008; Paterne et al., 2008). This tephra has been found in marine sediments from the Ionian Sea (Paterne et al., 2008) and in the lower part of the St. Germain I period at Monticchio (Brauer et al., 2007). Dating uncertainties remain for the Melisey 2 interstadial, which is dated to ca. $87,000 \mathrm{yr} \mathrm{BP}$ at Ohrid and ca. $89,000 \mathrm{yr}$ BP at Monticchio. The phase of forest expansion within the last glacial period, which is dated to around 50-45,000 yrs ago at Ohrid, closely corresponds to a warm event recorded in speleothem data from Villars in Southern France (Genty et al., 2003, 2005). This likely corresponds to the forest phase dated slightly earlier at Monticchio (Brauer et al., 2007), Ioannina (Tzedakis et al., 2002a), and Kopais (Okuda et al., 2001). At Villars, this event has been correlated with Dansgaard-Oeschger event 12 with exceptionally high speleothem growth rate and very low $\delta^{13} \mathrm{C}$ values (as low as $-11 \%$ ) attributed to dense vegetation growth. Based on 12 TIMS U-series dates, the optimum recorded by $\delta^{13} \mathrm{C}$ values is dated to $45,300 \pm$ 400 cal yr BP. The climate improvement responsible for forest expansion at Ohrid at that time is also reflected in the temporary increase of dissolved calcium concentrations that can be inferred from the discrete occurrence of good ostracod preservation (Fig. 4). It was however not sufficient to significantly revive the formation of authigenic calcite.

\subsection{Regional environmental changes}

Our multi-proxy record suggests that in response to an improvement of climate conditions, Lake Ohrid switched from a less to more productive ecosystem as early as 136,000 cal yr BP. The predominance of steppic herbaceous pollen types (mainly Artemisia and Chenopodiaceae) before that time indicates that steppe vegetation had dominated 


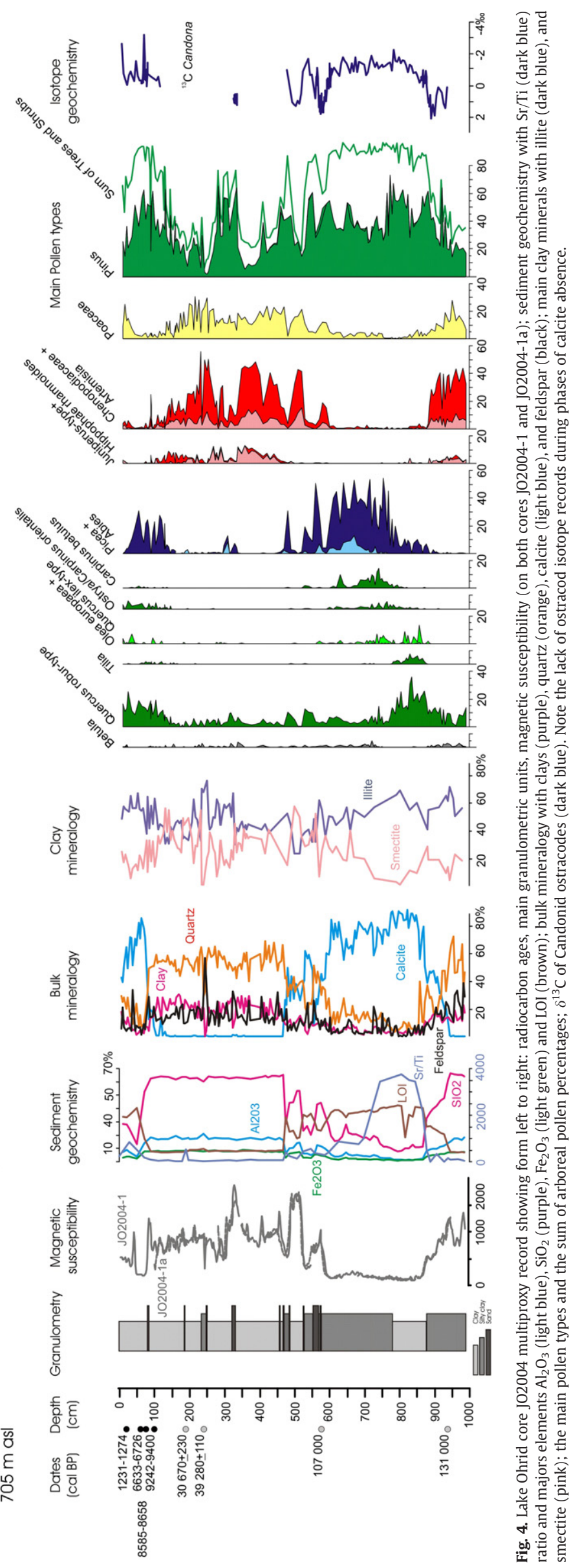



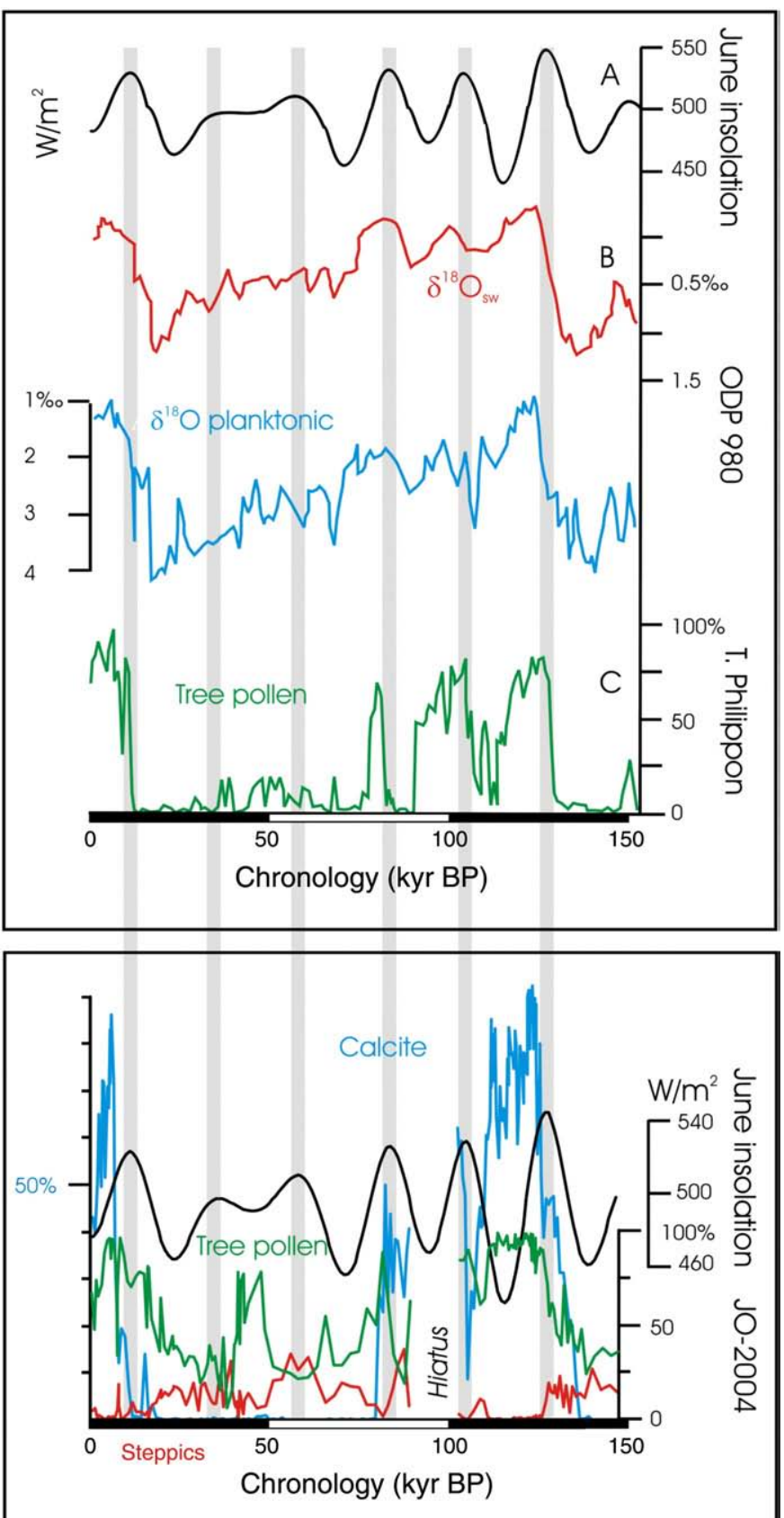

Fig. 5. Comparison between two independent chronologies of environmental changes in southern Europe. Upper panel: (A) June insolation curves for $65^{\circ} \mathrm{N}$, (B) benthic foraminiferal $\delta^{18} \mathrm{O}$ from ODP 980 (latitude: $55^{\circ} 29.1^{\prime} \mathrm{N}$ longitude: $14^{\circ} 42.1^{\prime} \mathrm{W}$ ), representing the ice volume/sea-level component of sea-water $\delta^{18} \mathrm{O}$, planktonicforaminiferal $\delta^{18} \mathrm{O}$ from core ODP 980, and (C) the tree-pollen percentage curve from Tenaghi Philippon plotted on the time scale of Tzedakis et al. (2003) (redrawn from Tzedakis (2005); see references therein). Lower panel: June insolation curves for $65^{\circ} \mathrm{N}$ (Berger, 1978), pollen percentage curves for steppe elements and trees, and the percent calcite content of core J0-2004 1 (this study) plotted on the same time scale. Grey vertical bars show the correspondence between the two independent data sets.

the immediate surroundings of the lake under a climate characterized by strong seasonal moisture deficiency. Marked seasonality in precipitation and runoff was responsible for the erosion of regional substrates (abundant illite, chlorite, $\mathrm{SiO}_{2}$ and $\mathrm{Al}_{2} \mathrm{O}_{3}$ ) as well as the development and removal of ophiolitic weathering profiles (smectite). From 136,000 to $127,000 \mathrm{yr} \mathrm{BP}$ a first prominent increase in calcite reflects the intensification of regional karst activity. The concomitant decrease in steppic vegetation elements, with mesic trees and smectite increase, suggests that climate conditions became progressively warmer and wetter.
However, soils were still poorly developed as indicated by the relatively high values of $\delta^{13} \mathrm{C}$ in ostracod calcite. At $128,000 \mathrm{yr}$ BP, a slight decrease in total arboreal pollen percentages together with an abrupt positive shift in ostracod $\delta^{13} \mathrm{C}$ of more than $1 \%$ and a plateau in calcite content suggest a short episode of climate deterioration interrupting the long-term warming trend. This pattern of environmental change has been recorded in several other climate-proxy records from southern Europe (e.g., Tzedakis et al., 2002a; Brauer et al., 2007; Gouzy et al., 2004). An abrupt, simultaneous shift in most proxies at $127,000 \mathrm{yr} B P$ marks the true beginning of the Last Interglacial period. The episode between 126,000 and $122,000 \mathrm{yr}$ BP is characterized by increased calcite precipitation within the lake as recorded by peak $\mathrm{CaCO}_{3}$ content $(>85 \%)$ and the large positive excursion of $\mathrm{Sr} / \mathrm{Ti}$. At that same time, Mediterranean trees expanded at the altitude of Lake Ohrid whereas cold steppes disappeared. Mesic forests developed on the adjacent slopes and conifer forest at higher altitude. This indicates that this period was unambiguously the warmest of the entire last interglacial. According to our data the thermal maximum was reached around 124,700 yr BP when Mediterranean vegetation elements widely expanding in southern European lowlands (e.g., Rousseau et al., 2006) reached the Lake Ohrid area at $800 \mathrm{~m}$ altitude. The end of this climatic optimum at 122,000 yr BP is marked by a dramatic shift in forest composition. Temperate and Mediterranean forest trees declined, whereas Carpinus- and Abiesdominated mixed forests, then Abies- and Picea-dominated conifer forests widely expanded with Abies proportion higher than those recorded anywhere in southern Europe (e.g., Reille et al., 2000; Tzedakis et al., 2002a; Pini et al., 2009; Allen and Huntley 2009), indicating the incursion of mountain environments into the lake basin and a progressive cooling. This is supported by the decreasing trend of calcite and increasing trend of detrital quartz during this interval. However, remarkably stable ostracod $\delta^{13} \mathrm{C}$ values around $-2 \%$ o throughout the period $127,000-110,000 \mathrm{yr}$ BP indicate that tree cover and related soil stability in this mountain environment were not affected by climate variations within the Last Interglacial.

Calcite minima and significant expansion of herbaceous steppic plant types at the expense of forest signal significant regional climate deterioration from 110,000 to 107,000 yr BP and around 87,000 yr BP, i.e. coeval with the Melisey 1 and 2 stadials, respectively. The cold climate conditions during stadials were responsible for poor soil development and enhanced erosion as recorded by the ostracodisotope and mineralogical records. The Saint Germain 1 and 2 interstadials are only partly recorded in Core JO2004-1 (Fig. 6). Although all proxies record climate improvement around 106,000 and $82,000 \mathrm{yr} \mathrm{BP}$, continued predominance of conifers at the expense of mesic trees in regional forests, and lower calcite content compared to that attained during the Last Interglacial suggest less favourable climate conditions and lower winter temperatures. This differs from what is observed at Ioannina ( $470 \mathrm{~m}$ altitude) in Northern Greece (Tzedakis et al., 2002a) where the two interstadials appear to have been remarkably similar in vegetation and climate conditions.

The abrupt fall in calcite content at the end of Saint Germain 2 (around 79,000 yr BP) shows that a lower temperature threshold was crossed, leading to at least seasonally frozen soil conditions at the elevation of the lake and probably permafrost in a large part of the mountain system. This is supported by the occurrence of periglacial landforms observed near the top of the Galicica mountain range (Belmecheri et al., 2009). Cold-tolerant trees such as Juniperus and Betula expanded together with steppic herbaceous plant types, similar to what occurred widely in southern Europe during the last glacial period (e.g., Allen et al., 1999; Allen and Huntley, 2009). However, the continuous presence of deciduous trees (albeit in low percentages) suggests that the forest refugia for mesic trees present at lower elevation at Ioannina (Tzedakis et al., 2002a) and in the nearby Maliq Basin (Denèfle et al., 2000) expanded up to 700-800 $\mathrm{m}$ in altitude to the shores of Lake Ohrid. The moderating lake effect on regional climatic conditions probably favoured their development at middle 

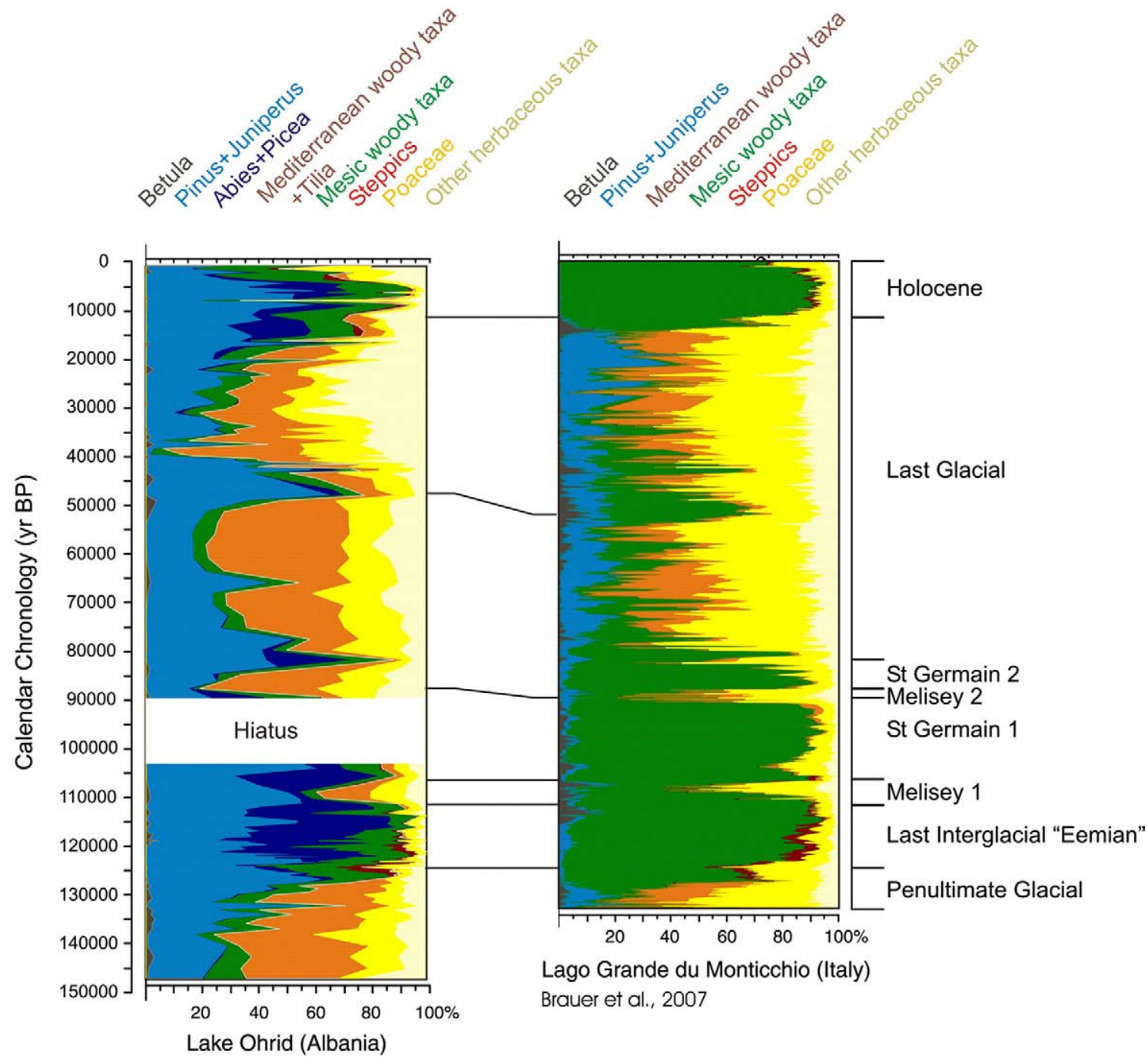

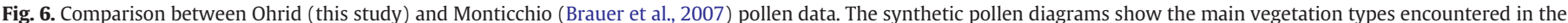

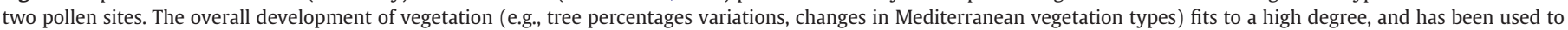

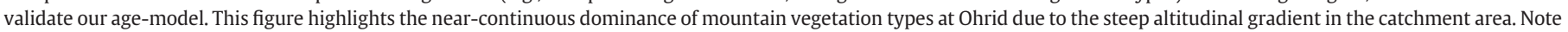
the gradual increase in tree pollen percentages at glacial-interglacial transitions.

altitudes in southern Albania. High-amplitude variation in the mineralogical composition of Ohrid sediments deposited between 50,000 and 18,000 cal yr BP indicate unstable environmental conditions during the glacial period. For example, alternating maxima of illite and smectite in the clay-mineral assemblages suggest variable erosion and weathering rates due to fluctuation of precipitation and/ or temperature, with illite maxima corresponding to intervals of enhanced precipitation and erosion.

The presence of refugia for mesic trees originating from the forest phase developed around 50-45,000 yr likely explain the surprisingly progressive last glacial-interglacial transition (Termination I) observed at Ohrid and Ioannina (Tzedakis, 2005) with mesic tree pollen types increasing regularly from $38,000 \mathrm{BP}$ to the Holocene (8800 cal yr BP). Authigenic calcite precipitation started to increase only at 17,000 cal yr BP, illustrating the delayed response of the lacustrine system to late-glacial warming. The increase of calcite was interrupted during the Younger Dryas, and then restarted from ca. $11,000 \mathrm{cal}$ yr BP to reach a maximum at $6000 \mathrm{cal} \mathrm{yr} \mathrm{BP}$. This rising trend was interrupted by an abrupt event of forest degradation probably coeval with the " $8.2 \mathrm{kyr}$ " cold event already recorded at Maliq (Bordon et al., 2009), corresponding to a $-2{ }^{\circ} \mathrm{C}$ cooling of annual temperature compared to mean Holocene values.

\section{Concluding remarks}

The most prominent feature in the recorded history of Lake Ohrid is the contrast between the responses of lacustrine and terrestrial environments to climate change throughout the last climatic cycle. Abrupt hydrological changes were controlled by the karstic system, which was active during interglacials and completely blocked during glacials in response to drastic deterioration of climate conditions. The abundance and strontium content of authigenic calcite and the $\delta^{13} \mathrm{C}$ of ostracod calcite appear to be sensitive proxies of temperature change during interglacials and help to detect and characterize the main fluctuations of climate within the interglacials and at the glacialinterglacial transitions. In contrast, the terrestrial environment recorded a more gradual evolution, particularly at the last glacialinterglacial transition. The Riss-Eemian (Termination II) and WürmHolocene (Termination I) climate transitions significantly differ from one another, with the lacustrine system reacting well before (by about 10,000 years) local vegetation change at the Riss-Eemian transition, and peak lake productivity lagging forest expansion by several thousand years at the Würm-Holocene transition. The interruption of the Wûrm glaciation by a moderate forest phase around 50-45 kyr, is probably one of the main causes of the presence of forest refugia 
which enabled, together with probable moderating effect of a large lake on local climate, the early expansion of forests during the WürmHolocene transition. We suggest that during the Riss glaciation no such moderate forest phase existed. The Riss glaciation is well known to have developed larger glaciated areas around the Alpes than the Würm (van Husen, 2004) and there is some evidence of larger, prewürm, glaciations in the area of Lake Ohrid. However, the corresponding moraines are not yet dated and continuous pollen records for the Riss glaciation are still lacking. In contrast, the delayed lake response to global warming at the last glacial-interglacial transition, shown by calcite production peaking at $6000 \mathrm{cal} \mathrm{yr} \mathrm{BP,}$ illustrate the threshold response of the geochemical system which was completely blocked during the late Würm glaciation. The succession of abrupt climate changes - especially the Bölling/Alleröd-Younger Dryas sequence and the " $8.2 \mathrm{kyr}$ cold event" - in this mountainous area probably accentuated this delay.

By using a large range of paleoenvironmental proxies we were able to detect climate changes even during glacial phases when calcite and the associated stable isotope records are lacking. This study illustrates the great potential of Lake Ohrid as an archive of southern European/ Mediterranean climate and environment over the entire Quaternary.

\section{Acknowledgements}

This work was supported by CNRS grants from the French ECLIPSE program. Thanks are due to G. Touchais (French School of Athens, Greece and Paris 1 University, France) and P. Lera (Archaeological museum of Korçë, Albania) for their support during fieldwork and authorizations, to S. Desruelle (Paris XII University, France) for drawing and to A. Bitri, J.-J. Chateauneuf (BRGM, Orléans, France), A. Brauer (Potsdam, Germany), J.-L. de Beaulieu (CNRS, Aix-en-Provence, France) and D. Verschuren (University of Gent, Belgium) for the helpful discussions. H. Hooghiemstra and the second anonymous reviewer are acknowledged for their helpful suggestions to improve the manuscript. AMS dating was provided by UMS-ARTEMIS (Saclay, France) AMS Facilities. LSCE contribution no. 3902.

\section{References}

Aksu, A.E., Jenner, G., Hiscott, R.N., İşler, E.B., 2008. Occurrence, stratigraphy and geochemistry of Late Quaternary tephra layers in the Aegean sea and the Marmara sea. Mar. Geol. 252 (3-4), 174-192.

Allen, J.R.M., Huntley, B., 2009. Last Interglacial palaeovegetation, palaeoenvironments and chronology: a new record from Lago Grande di Monticchio, southern Italy. Quat. Sci. Rev. 28 (15-16), 1521-1538.

Allen, J.R.M., Brandt, U., Brauer, A., Hubberten, H.W., Huntley, B., Keller, J., Kraml, M., Mackensen, A., Mingram, J., Negendank, J.F.W., Nowaczyk, N.R., Oberhänsli, H., Watts, W.A., Wulf, S., Zolitchka, B., 1999. Rapid environmental changes in southern Europe during the last glacial period. Nature 400, 740-743.

Bard, E., 1998. Geochemical and geophysical implications of the radiocarbon calibration. Geochim. Cosmochim. Acta 62, 2025-2038.

Belmecheri, S., Namiotko, T., Robert, C., von Grafenstein, U., Danielopold, D.L., 2009. Climate controlled ostracod preservation in Lake Ohridnext term (Albania, Macedonia). Palaeogeogr. Palaeoclimatol. Palaeoecol. 277 (3-4), 236-245.

Berger, A., 1978. Long-term variations of caloric insolation resulting from the earth's orbital elements. Quatern. Res. 9, 139-167.

Bordon, A., 2009. Dynamique de la vegetation et vériations climatiques dans les Balkans au cours du dernier cycle climatique à partir des séquences polliniques des lacs Maliq et Ochrid (Albanie). Unpublished Thesis, University of Franche-Comté.

Bordon, A., Peyron, O., Lézine, A.-M., Brewer, S., Fouache, E., 2009. Late-Glacial and Holocene climate in southern Balkans (Lake Maliq) from pollen data. Quat. Int. 200 (1-2), 19-30.

Brauer, A., Allen, J.R.M., Mingram, J., Dulski, P., Wulf, S., Huntley, B., 2007. Evidence for last interglacial chronology and environmental change from Southern Europe. PNAS 104 (2), 450-455.

Brewer, S., Guiot, J., Sanchez-Goni, M.-F., Klotz, S., 2008. The climate in Europe during the Eemian: a multi-method approach using pollen data. Quatern. Sci. Rev. 27, 2303-2315.

Calanchi, N., Dinelli, E., 2008. Tephrostratigraphy of the last 170 ka in sedimentary successions from the Adriatic Sea. J. Volcanol. Geotherm. Res. 177, 81-95.

Campbell, I.B., Claridge, G.G.C., 1998. The influence of moisture on the development of soils of the cold deserts of Antarctica. Geoderma 28, 221-238.

Caron, B., Sulpizio, R., Zanchetta, G., Siani, G., Santacroce, R., submitted for publication. The Late Holocene to Pleistocene tephrostratigraphic record of Lake Ohrid (Albania). C. R. Geoscience.

Chamley, H., 1989. Clay Sedimentology. Springer.
Chester, P.I., Raine, J.I., 2001. Pollen and spores keys for Quaternary deposits in the northern Pindos mountains, Greece. Grana 40, 299-387.

Civetta, L., Cornette, Y., Crisci, G., Gillot, P.Y., Orsi, G., Requejo, C.S., 1984. Geology, geochronology and chemical evolution of the island of Pantelleria. Geol. Mag. 121, 541-562.

Civetta, L., Cornette, Y., Gillot, P.Y., Orsi, G., 1988. The eruptive history of Pantelleria. (Sicily Channel) in the last 50 ka. Bull. Volcanol. 50, 47-57.

De Vivo, B., Rolandi, G., Gans, P.B., Calvert, A., Bohrson, W.A., Spera, F.J., Belkin, H.E 2001. New constraints on the pyroclastic eruptive history of the Campania volcanic Plain (Italy). Mineral. Petrol. 73, 47-65.

Denèfle, M., Lézine, A.-M., Fouache, E., Dufaure, J.J., 2000. First pollen data from Albania: a 12,000 years history of Lake Maliq. Quatern. Res. 54, 423-432.

Di Vito, M., Sulpizio, R., Zanchetta, R., D'Orazio, M., 2008. The late Pleistocene pyroclastic deposits of the Campanian Plain: new insights on the explosive activity of Neapolitan volcanoes. J. Volcanol. Geotherm. Res. 177 (1), 19-48.

Dumurdzanov, N., Serafimovski, T., Burchfiel, B.C., 2005. Cenozoic tectonics of Macedonia and its relation to the South Balkan extensional regime. Geosphere 1, 1-22.

Eugster, H.P., Kelts, K., 1983. Lacustrine chemical sediments. In: Goudie, G., Pye, K. (Eds.), Chemical sediments and Geomorphology. London, Academic Press, pp. 321-368.

Faegri, K., Iversen, J., 1989. Textbook of pollen analysis, 4th edition. John Wiley \& Sons, New York.

Genty, D., Blamart, D., Ouahdi, R., Gilmour, M., Baker, A., Jouzel, J., Van-Exter, S., 2003. Precise dating of Dansgaard-Oeschger climate oscillations in Western Europe from stalagmite data. Nature 421, 833-837.

Genty, D., Combourieu Nebout, N., Hatté, C., Blamart, D., Ghaleb, B., Isabello, L., 2005. Rapid climatic changes of the last 90 kyrs recorded on the European continent. C. R. Geosciences 337 (10-11), 970-982.

Giaccio, B., Isaia, R., Fedele, F.G., Di Canzio, E., Hoffecker, J., Ronchitelli, A., Sinitsyn, A.A., Anikovich, M., Lisitsyn, S.N., Popov, V.V., 2008. The Campanian Ignimbrite and Codola tephra layers: two temporal/stratigraphic markers for the Early Upper Palaeloithic in southern Italy and eastern Europe. J. Volcanol. Geotherm. Res. 177 (1), 208-226

Gouzy, A., Malaizé, B., Pujol, C., Charlier, K., 2004. Climatic « pause » during Terminaison II identified in shallow and intermediate waters off the Iberian margin. Quat. Sci. Rev. 23 (14-15), 1523-1528.

Keller, J., Ryan, W.B.F., Ninkovich, D., Altherr, R, 1978. Explosive volcanic activity in the Mediterranean over the past 200,000 yrs as recorded in deep-sea sediments. Geol. Soc. Amer. Bull. 89, 591-604.

Klie, W., 1939a. Studien über Ostracoden aus dem Ohridsee: I. Candocyprinae. Archiv. Hydrobiol. 35, 28-45.

Klie, W., 1939b. Studien über Ostracoden aus dem Ohridsee: II. Limnocytherinae und Cytherinae (Nebst der Beschreibung einer neuen Leptocythere-Art. aus einem Flusse des Stromgebietes der Donau). Archiv. Hydrobiol. 35, 631-646.

Klie, W., 1942. Studien über Ostracoden aus dem Ohridsee: III. Erster Nachtrag. Archiv. Hydrobiol. 38, 254-259.

Kraml, M., 1997. Laser-40Ar/39Ar-Datierungen an distalen marinen tephren des jungquartären mediterranen Vulkanismus (Ionisches Meer, METEOR-Fahrt 25/4) Ph.D. Thesis, Albert-Ludwigs Universität Freiburg i.Br.

Lézine, A.-M., Saliège, J.-F., Robert, C., Werth, F., Inizan, M.-L., 1998. Holocene lakes from Ramlat-as Sab'atayn (Yemen) illustrate the impact of monsoon activity in Southern Arabia. Quatern. Res. 50, 290-299.

Mahood, G.A., Hildreth, W., 1986. Geology of the peralkaline volcano at Pantelleria strait of Sicily. Bull. Volcanol. 48, 143-172.

Marianelli, P., Sbrana, A., 1998. Risultati di misure standard di minerali e di vetri naturali in microanalisi a dispersione di energia. Atti Soc. Tosc. Sci. Nat. 105, 57-63.

Matzinger, A., Spirkovski, Z., Patceva, S., Wüest, A., 2006. Sensitivity of ancient Lake Ohrid to local anthropogenic impacts and global warming. J. Great Lakes Res. 32, 158-179.

Mikulić, F., 1961. Nove Candona vrste iz Ohridskog Jezera. Bull. Mus. Hist. Nat. Belgrade 17B, 87-107.

Nicot, J., Chardon, M., 1983. On the morphotectonic background and the evolution of natural environments and limestone relief in Western Yugoslavian Macedonia. Méditerranée 37-52 in French.

Okuda, M., Yasuda, Y., Setoguchi, T., 2001. Middle to Late Pleistocene vegetation history and climatic changes at Lake Kopais, Southeast Greece. Boreas 30, 73-82.

Paterne, M., Guichard, F., Duplessy, J.-C., Siani, G., Sulpizio, R., Labeyrie, J., 2008. A $90,000-200,000$ yrs marine tephra record of Italian volcanic activity in the Central Mediterranean Sea. J. Volcanol. Geotherm. Res. 177 (1), 187-196.

Petschick, R., 1998. Mac Diff version 3. Online: http://www.servermac.geologie.unifrankfurt.de.

Pini, R., Ravazzi, C., Donegana, M., 2009. Pollen stratigraphy, vegetation and climate history of the last $215 \mathrm{ka}$ in the Azzano Decimo core (plain of Friuli, north-eastern Italy). Quatern. Sci. Rev. 28 (13-14), 1268-1290.

Pyle, D.M., Ricketts, G.D., Margari, V., van Andel, T.H., Sinitsyn, A.A., Praslov, N.D., Lisitsyn, S., 2006. Wide dispersal and deposition of distal tephra during the Pleistocene 'Campanian Ignimbrite/Y5' eruption, Italy. Quatern. Sci. Rev. 25 (2122), 2713-2728

Reille, M., 1992. Pollen and spores of Europe and North Africa. Laboratoire de botanique historique et palynologie, Marseille. in French.

Reille, M., de Beaulieu, J.-L., Svobodova, H., Andrieu-Ponel, V., Goeury, C., 2000. Pollen analytical biostratigraphy of the last five climatic cycles from a long continental sequence from the Velay region (Massif Central, France). J. Quatern. Sci. 15 (7), 665-685

Roelofs, A.K., Kilham, P., 1983. The diatom stratigraphy and paleoecology of Lake Ohrid, Yugoslavia. Palaeogeogr. Palaeoclimatol Palaeoecol. 42, 225-245.

Rousseau, D.D., Hatté, C., Guiot, J., Duzer, D., Schevin, P., Kukla, G., 2006. Reconstrction of the Grande Pile Eemian using inverse modelling of biome and $\delta^{13} \mathrm{C}$. Quatern. Sci. Rev. 25 (21-22), 2806-2819. 
Sánchez Goñi, M.-F., 2007. Introduction to climate and vegetation in Europe during MIS5. Develop. Quatern. Sci. 7, 197-205.

Sánchez Goñi, M.-F., Eynaud, F., Turon, J.-L., Shackleton, N.J., 1999. High resolution palynological record off the Iberian margin: direct land-sea correlation for the Last Interglacial complex. EPSL 171 (1), 123-137.

Sánchez Goñi, M.-F., Loutre, M.-F., Crucifix, M., Peyron, O., Santos, L., Duprat, J., Malaizé, B., Turon, J.-L., Peypouquet, J.-P., 2005. Increasing vegetation and climate gradient in Western Europe over the Last Glacial Inception (122-110 ka): data-model comparison. EPSL 231 (1-2), 111-130.

Sirocko, F., Claussen, M., Litt, T., Sánchez Goñi, M.-F., Berger, A., Boettger, T., Diehl, M. Desprat, S., Delmonte, B., Degering, D., Frechen, M., Geyh, M.A., Groeger, M., Kageyama, M., Kaspar, F., Kühl, N., Kubatzki, C., Lohmann, G., Loutre, M.-F., Müller, U., 2007. Chronology and climate forcing of the last four interglacials. Develop. Quatern. Sci. 7, 597-614.

Stabel, H.H., 1986. Calcite precipitation in Lake Constance: chemical equilibrium, sedimentation, and nucleation by algae. Limnol. Oceanogr. 31, 1081-1093.

Stankovic, S., 1960. The Balkan Lake Ohrid and its Living World. Den Haag.

Stuiver, M., Reimer, P.J., Reimer, R.W., 2005. CALIB 5.0. WWW program and documentation]. http://calib.qub.ac.uk/calib/.

Talbot, M.R., Allen, P.A., 1996. Lakes. In: Reading, M.G. (Ed.), Sedimentary Environments. Blackwell, London, pp. 83-124.

Tzedakis, P.C., 2005. Towards an understanding of the response of southern European vegetation to orbital and suborbital climate variability. Quatern. Sci. Rev. 24, 1585-1599.

Tzedakis, P.C., Lawson, I.T., Frogley, M.R., Hewitt, G.M., Preece, R.C., 2002a. Buffered tree population changes in a Quaternary refugium: evolutionary implications. Science 297, 2044-2047.
Tzedakis, P.C., Frogley, M.R., Heaton, T.H.E., 2002b. Duration of last interglacial conditions in Northwestern Greece. Quatern. Res. 58, 53-55.

Tzedakis, P.C., Manus, P.C., Hooghiemstra, H., Oppo, D.W., Wijmstra, T.A., 2003. Comparison of changes in vegetation in northeast Greece with records of climate variability on orbital and suborbital frequencies over the last 450,000 years. EPSL 212, 197-212.

Tzedakis, P.C., Hooghiemstra, H., Palike, H., 2006. The last 1.35 million years at Tenaghi Philippon: revised chronostratigraphy and long-term vegetation trends. Quatern. Sci. Rev. 25, 3416-3430.

van Husen, D., 2004. Quaternary glaciation in Austria. Develop. Quatern. Sci. 2 (1), 1-13.

Wagner, B., Sulpizio, R., Zanchetta, G., Wulf, S., Wessels, M., Daut, G., Nowaczyk, N., 2008a. The last 40 ka tephrostratigraphic record of Lake Ohrid, Albania and Macedonia: a very distal archive for ash dispersal from Italian volcanoes. J. Volcanol. Geotherm. Res. 177, 71-80.

Wagner, B, Reicherter, K, Daut, G., Wessels, M., Matzinger, A., Schwalb, A., Spirkovski, Z. Sanxhaku, M., 2008b. The potential of Lake Ohrid for long-term palaeoenvironmental reconstructions. Palaeogeogr. Palaeoclimatol. Palaeoecol. 259, 341-356.

Weaver, C.E., 1989. Clays, Muds, and Shales. Elsevier.

Wulf, S., Brauer, A., Mingram, J., Zolitschka, B., Negendank, J.F.W., 2006. Distal tephra in the sediments of the Monticchio maar lakes. In: Principe, C. (Ed.), La Geologia del Monte Vulture, pp. 115-122.

Zanchetta, G. Sulpizio, R., Giaccio, B., Siani, G., Paterne, M., Wulf, S., D'Orazio, M., 2008. The Y-3 tephra: a stratigraphic marker for the Last Glacial successions of the Central Mediterranean Basin. J. Volcanol. Geotherm. Res 177 (1), 145-154. 